\title{
Discourse of Pakistan's Identity under Strand of Liberal Citizenship: A Case Study of Musharraf Education Policy Reforms
}

\author{
Shafique Qurban ${ }^{1}$, Husnul Amin*1-2 \& Maryam Siddiqa ${ }^{3}$
}

1. Department of Politics \& International Relations, International Islamic University Islamabad, Pakistan.

2. South Asia Centre, University of Pennsylvania, Pennsylvania, Philadelphia, United States.

3. Iqbal Institute of Research \& Dialogue, International Islamic University, Islamabad, Pakistan.

Received: April 16, 2020

Published Online: November 25, 2020

\begin{abstract}
Keeping in view the political shifts in the wake of $9 / 11$ incident, new social and political trends/concepts have emerged which affected the nations across the world particularly the Muslim world, wherein a wave of extremism and conservatism was seen to be set in. In consequence, Pakistan embarked upon to make reforms in the curriculum to avoid that wave. Accordingly, Musharraf government has adopted education reform under the banner of enlightened moderation and introduced curriculum to construct Pakistani nationalism in the context of liberal citizenship to curtail the issues like extremism and conservatism spread under the slogan of Islamization. This study pinpoints the overall impact of Musharraf policy changes upon curriculum and its role in the construction of liberal citizenship. This study uses secondary data in the shape of policy texts and curriculum of social studies. This study uses discourse analysis to analyse policy text and curriculum. The findings of the study have pointed out that the government has introduced modern contents such as life skills and scientific knowledge to tackle prevailing issues by removing biased and outdated contents from existing curricula. This study has recommended that effective policy measures to construct liberal citizenship should only be realized with effective implementation.
\end{abstract}

Keywords: Conservatism, Curriculum Reforms, Education Policy, Enlightened Moderation, Extremism, Liberal Citizenship, Pakistani Identity.

\section{Introduction}

The incident of 9/11 has changed the dynamics of world politics and influenced the states to reshape their educational plan to reform curricula to promote certain norms and values for state buildings (Green, 1990) according to the evolving trends of the world. This event mainly targeted the education system in Muslim countries, particularly Pakistan, as being orthodox and conservative to spread extremism and terrorism. Keeping in view the criticism around the World, the Musharraf government has introduced a narrative of enlightened moderation to reform the curricula to construct Pakistani identity and citizenships on modern patterns according to the World's requirements. Musharraf government has reversed Islamization ideology in the education system initiated by Zia by removing all irrelevant Islamic contents from curricula, especially from English, Urdu, social studies (Chughtai, 2015). His government has started to remove conservative and orthodox contents by inserting new themes based on civic and ethical values to construct liberal citizenship in Pakistan. This research is designed to 
conduct a comparative study of curricula reform by Ayub, Zia, and Musharraf regimes to develop nation building and state building (Kazi, 1994). This research has explained that these regimes had used textbooks as the medium of indoctrinating their ideology (Smith, 1991) to construct their required national identities and citizenship. This research is focused on Musharraf curricula reform to reverse the discourse of Islamized identity into a liberal identity for society's development to meet the needs of the time.

Since the inception of Pakistan in 1947, the government of Pakistan had to use education policy to promote his ideology in the shape of national curricula to re-imagine the national identity due to being ethnically diverse and the reign hub of colonial rule. Since then, governments have been controlling national curricula the curricula of history in Islamic context to bind all the people in the main social web to ensure social harmony and develop a single identity by the name of Pakistani (Aziz, 1993; Saigol, 2003; Durani \& Dunne, 2010; Qurban \& Amin, 2019). Ayub government under the second educational policy by the name of Sharif Commission Report had developed an idea to introduce history at primary level through the subject of social studies (Salim \& Khan, 2004; Faizi et al., 2012; Qurban \& Amin, 2019). The subject of social studies was based on three different subjects; history, geography and the culture of Pakistan. The curricula of social studies and its textbook contain the main material from ancient civilizations as well as teachings of Islam. The prime purpose of this subject was to inculcate homogeneous vision among the students, which are mostly influenced by the moderate narrative of Islam (Ahmad, 2004; Faizi et al., 2012). The basic purpose behind this moderate homogenous vision was a single discourse of national identity, which is called Pakistani nationality (Durani \& Dunne, 2010; Qazi \& Shah, 2019).

It is worth mentioning that the Ayub government under its educational policy agenda promoted a discourse of Pakistani identity in a liberal context (Kadiwal \& Jain, 2020). However, the Zia government under the narrative of Muslim Ummah reversed the discourse of liberal Pakistani identity promoted under the reign of Ayub. Zia regime had changed the discourse of national identity by emphasizing only upon "Muslim history" with the main objective to develop hegemony of Islam in the future generation of Pakistan by removing contents of ancient civilizations from the textbooks (Salim \& Khan, 2004; Lall, 2008; Ahmed, 2017). Besides, Ziaul-Haq's policy developed orthodoxy in society and promoted militaristic regimes significantly, which was contrary to our liberal agenda (Durani \& Dunne, 2010; Qurban \& Amin, 2019).

In the aftermath of $9 / 11$, bottles were spanned around. The western world started criticizing that the national curricula were the prime ingredient breeding hatred, extremism and terrorism among the younger ones. Thus, owing to momentous stress by the world and decaying situation of Pakistani society, the Musharraf's government at that time introduced reforms in the national curricula. He gave the concept of enlightened moderation. These reforms had a basic objective to promote tolerance, to develop a lawful society in Pakistan and to eradicate hatred and agony from society from its roots (Chughtai, 2015).

This research explored the content of social studies textbooks for 4th grade about identity related issues at a time when a previously dominant theocratic approach to education was shaken by several factors. The textbooks are the main carriers of ideology, which are influenced by politico-religious authorities that control the main memory of the future generations since it is the main instrument of social control. Islam was used as a tool to construct a homogeneous narrative to overcome ethnic differences that exist in Pakistan and to wipe out the colonial symbolism within this region (Zaidi, 2011; Ahmed, 2017; Qazi \& Shah, 2019). 
Different governments with their political agendas developed this content of social studies Textbooks for $4^{\text {th }}$ grade. These political agendas were introduced to construct Pakistani Identity according to changing circumstances, which were more adjustable to the agenda of the government of the time. The curricula of social studies for $4^{\text {th }}$ grade in Pakistan have been witnessing the history of systemic changes in the ideological narrative of Pakistan therein due to the changing agendas of the produced education policies 1947, 1959, 1969, 1970, 1972, 1979, 1992 and 1998. The education policies of 1947, 1959, 1969, 1970 and 1972 have produced shared values for the construction of Pakistani identity in South Asian context inspired from the values of universal brotherhood, equality, social justice, democracy and teaching of Islam (Siddiqui, 2016; Qurban \& Amin, 2019). While education policies of 1979, 1992 and 1998 constructed the Pakistani identity in the context of "Muslim Ummah" to develop law-abiding and loyal Muslim citizens (Qurban \& Amin, 2019). Furthermore, the textbooks also tended to promote identity and loyalty to Muslim Ummah (a global Muslim unity) by segregating the world into Muslims and non-muslims to construct a sense of Us v/s Them (Salim \& Khan, 2004; Lall, 2008; Qazi \& Shah, 2019).

The comparative analysis of social studies textbooks given in the appendix (1,2 and 3 ) has clearly provided changing the narrative of identity by different regimes, which do not only provide the regional but also a global aspect of the citizenship. Henceforth, different governments according to their own ideologies developed the curriculum of social studies. This changing narrative in ideology by governments has been noticed by different writers (Aziz 1993, Saigol 2003, Nayyar \& Saleem 2005; Ahmad, 2004) in name of the discontinuity and flaws in the national curricula. These flaws further highlighted that governments' policies were not systematic; neither had they wanted to develop a prolific society (Salim \& Khan, 2004; Qurban \& Amin, 2019).

\section{Theoretical Approach}

The first comprehensive education policy was formulated by Ayub Khan, which promoted the idea of pluralistic society by introducing moderate teachings of Islam in curricula especially in social studies. Ayub government was intended to develop Pakistani citizenship in a global context by bridging cultural and historical ties with Asia, Europe, Middle East and the United States to assert a heritage enriched with multicultural values and pride of having worthy national assets (Siddiqui, 2016). The foremost point of this policy was to foster indigenous social and cultural patterns to reform the social inequalities for establishing a prosperous society. This piece of legislation had banned on repugnant material in religious courses that caused division within citizenship (Report of the Commission on National Education, 1959:209; Qurban \& Amin, 2019). The prime objective of Ayub's education policy was to develop pluralistic society wherein ideology of Pakistan was informed from "Two Nation Theory" based on socio-political and economic deprivation of Muslims in Sub-Continent to construct Pakistani identity into liberal context.

The Nur Khan Report in 1969 had changed the pluralistic narrative of history by re-forming notion of Two Nation Theory on Islamic values and Indian enmity as a framework of developing national cohesion (Proposals for a New Educational Policy, 1969; Siddiqui, 2016; Qurban \& Amin, 2019). The education policy of 1972 went further ahead by adding chapters on Pakistan ideology, Islamic culture in social studies at the primary level (Education Policy of 1972, 1972; Salim \& Khan, 2004). 
The education policy of 1979 initiated the process of Islamization and reformed curricula of all subjects, especially Social Studies and Pakistan Studies (National Education Policy and Implementation Programme, 1979; Qurban \& Amin, 2019). This reform scheme completely removed the contents of ancient history and civilization with Muslim heroes' stories and Muslim history. The new curriculum of social studies abruptly skipped ancient history while introducing the history of Muhammad Bin Qasim (Rahman, 1996). It consisted of seven chapters on personalities including the Holy Prophet, Four Caliph, Father of Nation Jinnah and Muhammad Iqbal (Aziz, 1993; Qazi \& Shah, 2019).

The education policy of 1992 propagated the idea of Islamic social studies (National Education Policy 1992, 1992:41). The education policy of 1998 thus followed the scheme of the Islamization trend of previous policies (1979 and 1992) and focused on the insertion of Islamic teachings and Quranic verses to foster moral values in the young generation based on Islamic tenets (Education Policy of 1998-2008, 1998; Salim \& Khan, 2004; Qurban \& Amin, 2019). However, the narrative of Islamization was abruptly changed by Musharraf regime under enlightened moderation which s has been clearly depicted in the key objective of National Education Policy of 2009 was "to raise individuals committed to democratic and moral values, aware of fundamental human rights, open to new ideas, having a sense of personal responsibility and participation in the productive activities in society for the common good" (National Education Policy 2009, Pakistan, 2009:11).

\section{Research Methodology}

This research uses Theory of Governmentality advocated by Foucault that states governments in the modern states use education as an instrument to construct and re-construct national identities. For him, the basic purpose is to control individuals and society's behaviour at large. In the Governmentality Theory, Foucault believed that in a broader sense, the modern governments use education as a soft power to get a hold on the minds and activities of the individuals to make them more loyal and responsible citizens of the State (Dean, 1999).

The theory presented by Foucault is used later in terms of modern trends of government studies such as recent changes in political system and relationship between citizens and state specifically with the emergence of neoliberal governments in the world. The scholars are of the view that modern government using education has been trying to produce skilled human capital to compete in the world market. Education is used as a normalizing force to train citizens for being self-responsible and contributing to the development of society (Dean, 1999). It is believed that knowledge in the modern world is used for reforming workers, people and students to active members of society (Naseem, 2010:17). This research focuses on the way education was used as mentioned in Foucault's Governmentality Theory to promote a specific idea of identity and citizenship narrated in General Pervez Musharraf era.

This research was primarily informed by the official statements presented in education policies and official documents of the curriculum, which were developed under the impact of the changing social-political dynamics. This research was based on education policy documents produced in 1959, 1969, 1970, 1972, 1979, 1992, 1998 and 2009. It also informed from Social Studies textbooks for 4thgrade published in 1965, 19981, 2002 and 2012. For analysis of these policy statements in education policies and curriculum document, this research has used Discourse Analysis (DA) as is the mainframe of analysis. Discourse Analysis is a most suitable technique for this research because as it provided a frame on the identification of particular 
discourse, as this research had its focus on the changing nature of discourse in shaping ideologies within the education policies texts. It gave the notion that social reality was constructed rather than being considered as natural.

\section{Discourse of Pakistan's Identity: A Comparative Analysis}

The curriculum had shifted the plot of identity for future Pakistani cohort from Arab Muslim identity to South Asian. The considerable new themes and contents had been added in curricula of 2002 with an austere shift from the previous curricula developed by Zia and successive regimes. However, the curriculum of 2002 developed the Musharraf regime before the slogan of enlightened moderation was more alike in contents with previous regimes curricula. The stark shift in the narrative of contents came in the curriculum of 2006. It provided a restructured format of knowledge more well-suited to the global requirement. It provided broad knowledge about the rights and duties of citizens. Curricula imparted contents for being updated about current problems, their solutions and at most their alternatives.

The curriculum of 2006 was centred on the student. This curriculum had apposite guidance about methods of assessment for students. It was devised with the intention to wipe-out root learning and to encourage creative and critical thinking among students. The curriculum of 2006 facilitated frame of constructing inclusive identity by valuing multiplicity and equality for all. It also provided grounds to construct compassion, impartiality, integrity, humanism, even-handedness, and tolerance for sustainable co-existence and an agreement among people and other ethnic groups. It encouraged the narrative of being informed about socio-political, economic and scientific growth to get involved in it, as being global citizens with enough intelligence and awareness to go for progressive ways. This curriculum framework encouraged a liberal line of direction for societal development. The ideological narrative had been entirely shifted from confrontational or conservative Islam to forbearing and moderate Islam.

Appendix 1, 2 and 3 have sketched-out a line of comparison between social studies curricula produced in 2006 in the shape of a textbook published in 2012 with previous schemes of textbooks. The curriculum of 2006 drew a stark shift in contents from previous one whereas the curriculum of 2006 thoroughly skipped the narrative of Muslim history, jihad and the discourse about enmity against minorities particularly about Hindus that was present in former textbooks. This curriculum focused on local history, cultural diversity, and knowledge about democracy, role government institutions and political parties in the country. The most interesting and purposeful element in the curriculum of 2006 were contents about problems such as population and climate and their solution. It also provided basic information about the global world rather than the Muslim world.

It is noticeable that the curricula of 2006 reflected a slight shift towards liberal citizenship and more open-ended learning experiences for students. The social studies mostly contained factual knowledge like history, geography, and civics, and the content promoted the dominant liberal ideology. The most viable and appropriate transformation in curriculum reform of 2006 was the amputation of religious political extremism from textbooks of social studies.

\subsection{A Narrative of History}

In Ayub's regime, the scope of social studies was construed on a broader perspective of history of the region from Indus civilization, the arrival of Aryans to Muslim rule in Subcontinent. The 
textbook of social studies in 1965 was covering a chapter on the ancient history of the subcontinent, which included a brief history regarding Indus Valley civilization and arrival of Arians to the region 4000 years ago. It had incorporated separate chapters on four seminal Caliphs of Islam. The curriculum also included the history of Mughal dynasty by providing detailed chapters on the reign of Baber, Akbar and Aurangzeb. This book had a detailed chapter on the rule of Sher Shah Suri. The most interesting feature of this book was having a complete episode on the first Muslim woman ruler and warrior Razia Sultana in the subcontinent.

However, the Zia regime had changed the narrative of history by exterminating ancient history in the Textbooks produced during his reign. In Zia's era, the brief history was reduced to mere footnotes, without any specifications. Zia regime had removed contents of ancient history and started a chapter of history from the advent of Islam in Subcontinent. The curriculum was only confined to the merits of Muslim rules. It had included chapters on personalities, which covered a separate chapter on Holy Prophet (SAW), four seminal Caliph (RA), Muhammad Ali Jinnah and Allama Iqbal. The textbook also had a complete chapter on Major Aziz Bhatti, a war hero of 1965. Zia had introduced a concept of teaching war heroes as a national hero in the textbooks. His regime had featured the textbook of history to be never unbiased, and this narrative was clearly visible in this curriculum as everything regarding religious ups and downs to Pakistan movement all inculcated Muslims Perspective only. The textbook had clearly focused on the difference between Hindu and Muslim.

After the incident of 9/11, Musharraf's administration spun the bottles trying to milk the cow as much as possible. His education plan revised the curriculum in the general text in the first phase and then equipped curriculum with ancient history and modern contents instead of a stern perspective during the second phase under enlightened moderation. The textbook produced during the first wave was having two chapters on women role in society. There was a complete chapter on the role Hazarat Khadija, a wife of Holy Prophet and the second chapter was on the role of Begum Salma Tassaduq in Pakistan movement. These two chapters were added to promote the notion of women empowerment with society and also to abolish the biases against women within society.

Musharraf regime had re-inserted chapters on the ancient history of the region including contents on Alexander the Great, Ashoka rule, Gautam Buddha, Muslim rule from Ghaznavi to Mughal rule and British rule. The Curricula of 2006 produced under the Musharraf regime paved the way for publication of textbook in 2012. The textbook of 2012 has set pattern of leaving no space for Islamic history especially about a chapter on Holy Prophet (SAW), and four seminal Caliphs (RA). It has incorporated chapters on other religious personalities such as Guru Nanak and Gautam Buddha. This textbook has followed a complete timeline of history in contrast to the Zia regime who had skipped events of centuries by focusing only on Muslim history. This book has covered the history of Punjab in the context of culture and traditions to make students aware of their indigenous culture as opposed to previous textbooks.

\subsection{The Content on War}

Social Studies Textbooks produced under the regime of Ayub lacked the content regarding Indo-Pakistan war. Certain norms of aggression during the reign of seminal caliphs were included. Yet, a different aspiration of Muslim rulers in sub-continent was induced that they prayed to God for victory, promising to abandon some immoral practices. 
Zia's education policy, similarly, did not include the history of regional wars, yet it highlighted the wars fought with India after independence. Kashmir issue was highlighted as a bone of contention between the two countries along with ethical differences. The textbook of 1981 had promoted narrative that India is the enemy of Pakistan and does not want to see Pakistan as an independent state. India has always been aggressive towards Pakistan and every time-imposed war on Pakistan. A separate chapter on War hero was incorporated in the textbook produced under the Zia regime.

The education policy at the time of Musharraf removed even those sections that highlighted war heroes. The chapters on war wars heroes were replaced with political heroes. However, the textbook of 2002 contained war content in the shape of 1965 war and textbook narrated that Pakistan defeated India. This textbook also took a stance on migration during partition that Hindu treated brutally to Muslim leaving for Pakistan while Muslim treated affectionately to Hindu leaving for India. Even the textbook of 2012 has no space for war contents. The textbook covers modern themes to make students aware of the importance of peace and the danger of war. The textbook covers that conflict leads to mental stress, devastation and war. It has incorporated separate chapters on peace and conflict resolution. It has also included four different methods of conflict resolution to make society war free. The book has promoted a narrative of Islam as a peaceful religion that only encourages peace, love and harmony and discourages war. The textbook thoroughly skipped chapters on war heroes by inserting chapters on Sufi saints and regional heroes. Musharraf government has first time incorporated a chapter on civil war of 1971 led by ethnicity and lingual differences.

\subsection{The Discourse of Others}

Social studies textbooks produced in the Ayub regime did not discuss non-Muslim in any special context. However, it had discussed origin by tracing it with Aryan and linking with a multicultural society. The textbooks had discussed Deen-e-Elahi and marriage of Akbar with Hindu woman. The textbook of 1965 had spoken positively for all other groups and promoted the idea of a pluralistic society.

On the other hand, the textbook produced under the regime of Zia promoted Hindu-Muslim differences and atrocities of Hindu against Muslims. It spoke about the opposition of Hindus during the British rule and brutal treatment of Hindus at the time of independence. The regime policy directives were clearly depicted in the textbook of 1981 wherein the textbook spoke favourably only for Muslim states particularly Saudi Arabia. This textbook promotes assimilation with Saudi Arabia as Pakistan is an Islamic state and respects the land of Mecca and Medina. The textbook promoted the narrative of Muslim Ummah by teaching only Muslim history. This book did not speak favourably about non-Muslims particularly Hindu.

Musharraf has a bit changed the narrative regarding non-Muslim. However, the textbook of 2002 sustained the Zia narrative regarding non-Muslims and declared Ranjeet Singh as cruel and inhuman towards Muslims. The textbook of 2012 has reverted the hostile narrative against non-Muslims promoted by the previous government under slogan enlightened moderation. The textbook amicably speaks about the role of non-Muslims. It has acknowledged the positive and constructive role of the British government in the development of the region. The contents of the textbook have promoted cultural diversity and social problems such as population and climate and their solutions. It has also provided basic information about the global world rather than the Muslim world. 


\section{Conclusion}

This study has found an impact of the changing regimes upon the formulation of policies and their role in the production of textbooks suitable for the construction of national identities as well as citizenship in Pakistan. The historical and comparative view of the textbooks during different regimes has revealed the truth that the narrative of Pakistani identity had been changed from pluralistic to conservative under the discourse of Muslim Ummah pronounced by the Zia regime and his successive governments. The narrative of ideology promoted by the Zia regime through curricula in the textbooks had escalated wave of extremism, intolerance and hatreds among the people. The textbooks produced under the Zia regime have provided the precedent that how a change in the narrative of curricula had severely impacted the construction of citizenship and process of nation buildings.

Musharraf government under the slogan of enlightened moderation had re-introduced narrative of pluralistic society by removing hatred contents as well as a narrative of wars from the textbook. The social studies textbook had new contents related to the prevailing social problems such as global warming, population, climate change and peace building. Musharraf government had promoted a discourse of tolerance, peace, harmony, human rights, democracy, personal responsibility, awareness about common goods and most equality of all through textbook among future generations to bind them into a web of social harmony for development of society. Musharraf government has introduced these values to re-construct Pakistani identity into the context of global citizenship. The analysis in appendices show systematic trends of changes in curricula and role of Musharraf government in the promotion of liberal citizenship values in the shape of democracy, human rights, personal responsibility, and awareness of common goods, harmony and tolerance through textbooks. It is concluded that the comparison of social studies textbooks produced under the Musharraf regime is much better than Ayub and Zia regime. The textbook of 2012 has clearly reverted Islamic narrative of Zia regime by promoting new themes to construct Pakistani citizenship in the context of liberal citizenship wherein citizens will be fully informed about modern trends and evils of society to transform into prosperous ones.

In light of all the data analysis, discussion, and findings, following are few recommendations of this study:

a) The textbooks must be developed under the scheme of 2006 curricula by all textbook boards by hook or by crook.

b) The government should implement the same curricula especially creating awareness about global issues at all levels and all corners of the state.

c) School teachers should be provided training to update them regarding modern knowledge provided therein the textbooks.

d) Successive governments should follow the same scheme of contents in the textbooks without experimentation of their own narrative of ideology.

e) The government must take appropriate policy measures to implement newly developed curricula ineffective measures. 


\section{References}

Ahmad, I. (2004). Islam, Democracy and Citizenship Education: An Examination of the Social Studies Curriculum in Pakistan. Current Issues in Comparative Education, 7(1), 3949. https://files.eric.ed.gov/fulltext/EJ853848.pdf

Ahmed, Z. S. (2017). National Identity Formation in Pakistan: An Analysis of the Anti-secular Narrative. Journal of Citizenship and Globalization Studies, 1(1), 63-73. https://doi.org/10.1515/jcgs-2017-0006

Ahmad, Z., Azam, U., \& Kavish, M. A. (2012). Social Studies 4 (1 ${ }^{\text {st }}$ Ed.). Urdu Book Stall. Aziz, K. K. (1993). The Murder of History in Pakistan. Vanguard.

Apple, M., \& Christian-Smith, L. (Eds.). (2017). The Politics of the Textbook. Routledge.

Chughtai, M. (2015). What Produces a History Textbook? (Doctoral dissertation, Harvard Graduate School of Education).

Dean, M. M. (1999). Governmentality: Power and Rule in Modern Society. Sage.

Durrani, N., \& Dunne, M. (2010). Curriculum and National Identity: Exploring the Links between Religion and Nation in Pakistan. Journal of Curriculum Studies, 42(2), 215240. https://doi.org/10.1080/00220270903312208

Faizi, W. U. N, Shakil, A. F., \& Akhtar, S. H. (2012). Consideration of Islamic Values in the Educational Policies of Pakistan. Journal of Educational and Social Research, 2(1), 297-297. https://doi.org/10.5901/jesr.2012.02.01.297

Green, A. (1990). Education and State Formation: The Rise of Education Systems in England, France and the USA. MacMillan.

Kadiwal, L., \& Jain, M. (2020). Civics and Citizenship Education in India and Pakistan. Handbook of Education. https://doi.org/10.1007/978-981-13-3309-5_44-1

Kazi, A. A. (1994). Ethnicity and Education in Nation-Building in Pakistan. Vanguard.

Lall, M. (2008). Educate to Hate: The Use of Education in the Creation of Antagonistic National Identities in India and Pakistan. Compare, 38(1), 103-119. https://doi.org/10.1080/03057920701467834

Muasharti Aloom Chauthi Jamat kay liay. (2002). Punjab Textbook Board.

Muasharti Aloom ka Practical Atlas: Grade 4. (1965). Anwar Book Depot.

Naseem, M. A. (2010). Education and Gendered Citizenship in Pakistan. In: Education and Gendered Citizenship in Pakistan (pp. 119-128). Palgrave Macmillan. https://doi.org/10.1057/9780230117914_8

Report of the Commission on National Education. (1959). Ministry of Education, Government of Pakistan.

Proposals for a New Educational Policy. (1969). Ministry of Education and Scientific Research, Government of Pakistan.

Education Policy of 1972. (1972). Ministry of Education, Government of Pakistan.

National Education Policy and Implementation Programme. (1979). Ministry of Education, Government of Pakistan.

National Education Policy 1992. (1992). Ministry of Education, Government of Pakistan. Education Policy of 1998-2008. (1998). Ministry of Education, Government of Pakistan. National Education Policy 2009. (2009). Ministry of Education, Government of Pakistan.

Nayyar, A. H., \& Salim, A. (2005). The Subtle Subversion: The State of Curricula and Textbooks in Pakistan Urdu, English, Social Studies and Civics. Sustainable Development Policy Institute.

Qazi, M. H., \& Shah, S. (2019). Discursive Construction of Pakistan's National Identity through Curriculum Textbook Discourses in a Pakistani School in Dubai, the United Arab 
Emirates. British Educational Research Journal,45(2), 275-297. https://doi.org/10.1002/berj.3496

Qurban, S., \& Amin, H. (2019). Education Policies, Discourse of Ideology and the Construction of National Identity in Pakistan: A Critical Analysis. Global Regional Review, 4(3), 1-9. https://doi.org/10.31703/grr.2019 (IV-III).01

Rahman, T. (1996). Language and Politics in Pakistan. Oxford University.

Saigol, R. (2003). History, Social Studies and Civics and the Creation of Enemies. In: S. A. Zaidi, Social Science in Pakistan in the 1990s (pp. 159-200). Council of Social Sciences.

Salim, A., \& Khan, Z. (2004). Messing Up the Past: Evolution of History Textbooks in Pakistan, 1947-2000. Sustainable Development Policy Institute.

Siddiqui, S. (2016). Education Policies in Pakistan: Politics, Projections, and Practices. Oxford University.

Smith, M. W. (1991). The Politics of the Textbook. In: M. W. Christian-Smith, The Politics of the Textbook (pp. 1-21). Routledge.

Yasmin, F., Hamid, A., Malik, B. U. D., \& Ahmad, Q. S. (1981). Social Studies for the Class $4\left(1^{\text {st }}\right.$ Ed.). Law Book House for Punjab Textbook Board.

Zaidi, S. M. A. (2011). Polarisation of social studies textbooks in Pakistan. The Curriculum Journal, 22(1), 43-59. https://doi.org/10.1080/09585176.2011.550770 


\section{Appendices}

Appendix 1: Change in Regime and Its Impact on Curriculum Social Studies for Grade 4

\begin{tabular}{|c|c|}
\hline Year & Social Studies for Grade 4 (Narrative of History) \\
\hline 1965 & $\begin{array}{l}\text { - The textbook covers information concerning four seminal caliphs of Islam; "Abu Bakar, } \\
\text { Omar, Usman, and Ali". } \\
\text { - The book gives details of Mughal emperors such as Babar, Akbar, Shah Jahan, and Aurangzeb. } \\
\text { - It also provides chapters on Sher Shah Suri - a Muslim king of the subcontinent and Razia } \\
\text { Sultana- a warrior and a Muslim woman ruler of the subcontinent. } \\
\text { - One of the chapters included in the textbook addresses ancient Indus Valley Civilization and } \\
\text { the Aryans who came to the region 4,000 years ago (Muasharti Aloom Ka Practical Atlas: } \\
\text { Grade 4, 1965, p. 3). }\end{array}$ \\
\hline 1981 & $\begin{array}{l}\text { - A chapter in the textbook depicting History of Punjab explains the history of the subcontinent } \\
\text { without mentioning wars, rulers or sultanates. } \\
\text { - The book highlights religious differences between Hindus and Muslims. It states that the } \\
\text { "inhabitants of these areas were impressed by the teachings of Islam and started to join its } \\
\text { fold. ... Although the Muslim rulers had allowed complete religious freedom to all non- } \\
\text { Muslims, yet the Hindus were inimical to Muslims" (Yasmin et al., 1981, p. 6). } \\
\text { - A chapter addresses Muslims' arrival to the sub-continent directly without mentioning the 7th } \\
\text { century A.D. date, to the Pakistan Movement in 1940. } \\
\text { - It speaks of the merits of the partition from a Muslim perspective only. } \\
\text { - Eight additional chapters provide information of five historic religious personalities (the } \\
\text { Prophet Muhammad, and four Caliphs) and Quaid-e-Azam Muhammad Ali Jinnah and Allama } \\
\text { Muhammad Iqbal and Major Aziz Bhatti-a war hero of } 1965 \text { war with India. }\end{array}$ \\
\hline 2002 & $\begin{array}{l}\text { - A chapter on Prophet Muhammad and chapters on only three of the four caliphs are given in } \\
\text { the textbook. } \\
\text { - One of the chapters gives details of Khadeja, the wife of Prophet Muhammad. } \\
\text { - Two of the chapters give details of Molana Zafar Ali Khan-a Punjabi man, and Begum Salma } \\
\text { Tassaduq Husain-a Punjabi woman who took part actively in Pakistan Movement (Muasharti } \\
\text { Aloom Chauthi Jamat kay liay, 2002). }\end{array}$ \\
\hline 2012 & $\begin{array}{l}\text { - A page entitled "Time Lines of Important Historical Events of the Province" (Ahmad et al., } \\
\text { 2012, p. 22) covers important personalities as well as time periods having a history of various } \\
\text { religions and regions. } \\
\text { - The } 2012 \text { textbook has sections on "Harappa Civilization; Aryan Civilization," "Mahatama } \\
\text { Gautam Buddha," "Attack of Alexander, the Great," "Ashoka's Period," "Arrival of } \\
\text { Mohammad Bin Qasim in Sindh and Multan," "Establishment of Ghaznavid's Regime," } \\
\text { "Ghauri Regime," "Salateen-e-Delhi Regime," "Birth of Baba Guru Nanak and the Beginning } \\
\text { of Sikhism," "Mughal Regime," "Suri Regime," "British Empire," "Establishment of Pakistan } \\
\text { and Partition of Punjab," "Abolishment of the Status of Province," and "Restoration of the } \\
\text { Status of Province" (Ahmad et al., 2012, pp. 23-31). } \\
\text { - Noticeably, in these chapters, nothing is mentioned concerning the history of Muslims } \\
\text { religious figures and Islam. No reference concerning Prophet Muhammad or any of four } \\
\text { caliphs is given. Not only does the textbook (Ahmad et al., 2012) leave out Islam, some } \\
\text { sections of the book cover renowned personalities of other faiths such as Sikhism and } \\
\text { Buddhism. } \\
\text { - The book comprehensively covers the history of the region chronologically. (Ahmad et al., } \\
\text { 2012) The creation of Pakistan is discussed in many sections in small parts rather than } \\
\text { depicting it as a primary focus of the book. Unlike the earlier textbooks discussion of Punjab } \\
\text { is included to familiarize students with the cultural, social, and historic identity of the } \\
\text { province. }\end{array}$ \\
\hline
\end{tabular}

Sources: Muasharti Aloom Ka Practical Atlas: Grade 4. (1965). Anwar Book Depot., Yasmin, F., Hamid, A., Malik, B. U. D., \& Ahmad, Q. S. (1981). Social Studies for Class 4 (1st Ed.). Law Book House for Punjab Textbook Board.; Muasharti Aloom Chauthi Jamat kay liay. (2002). Punjab Textbook Board.; Ahmad, Z., Azam, U., \& Kavish, M. A. (2012). Social studies 4 (1st Ed.). Urdu Book Stall. 
Appendix 2: Change in Regime and Its Impact on Curriculum Social Studies for Grade 4

\begin{tabular}{|c|c|}
\hline Year & 4 (Content on War) \\
\hline 1965 & $\begin{array}{l}\text { - Nothing is included concerning the Indo-Pak War. } \\
\text { - A chapter addressing the first Muslim caliph elaborates "norms of aggression by Islamic } \\
\text { religious leaders". It explains that in wars any crops, children, women, elderly and refugees } \\
\text { were not damaged following instructions. } \\
\text { - A chapter gives details through picture illustration (Muasharti Aloom Ka Practical Atlas: } \\
\text { Grade 4, 1965, p. 14) of Razia Sultana, daughter of King Altamash, the founder of the Delhi } \\
\text { Sultanate. She is portrayed as the most intelligent of all of Altamash's children, as someone } \\
\text { "with high military acumen who gave slaves the status of top military advisors" (Muasharti } \\
\text { Aloom Ka Practical Atlas: Grade 4, 1965, p. 14). } \\
\text { - A chapter on the Mughal emperor Babar describes that he made a promise with God that he } \\
\text { would give up alcohol if remained victorious in war. Muasharti Aloom Ka Practical Atlas: } \\
\text { Grade 4, (1965, p. 15). }\end{array}$ \\
\hline 1981 & $\begin{array}{l}\text { - The } 1981 \text { textbook (Yasmin et al., 1981) does not have any contents on regional wars of the } \\
\text { sub-continent. "However, it talks about two of the three wars Pakistan had fought with India } \\
\text { by then." The war with India over Kashmir in } 1948 \text { is narrated as a freedom struggle: as soon } \\
\text { as Pakistan was created in 1947, Jammu and Kashmir's Hindu Raja manoeuvred to accede to } \\
\text { Bharat [India]. Muslims of the state who were in majority and wanted to join Pakistan started } \\
\text { an armed struggle against the Hindu Raja and Army. Some freedom fighters from Pakistan } \\
\text { also joined Kashmiris in their efforts to get freedom and as a result, few of the areas of the } \\
\text { state were liberated. } \\
\text { - A section (Yasmin et al., 1981) discusses the } 1965 \text { war in an almost similar way. A chapter } \\
\text { on war hero Major Aziz Bhatti in the textbook provides paraphrasing of the same version of } \\
\text { that paragraph (p. 9). } \\
\text { - Bharat [India] has always been an enemy of Pakistan and has always been on the lookout } \\
\text { for an opportunity to harm our beloved country. Without declaring war, Bharat attacked } \\
\text { Lahore on September 6, 1965. Our brave army faced the enemy. Major Aziz Bhatti and his } \\
\text { handful of jawans [soldiers] stood like a rock in the face of the large Bharati [Indian] } \\
\text { battalion." (Yasmin et al., 1981, p. 76). }\end{array}$ \\
\hline 2002 & $\begin{array}{l}\text { - The chapters on war heroes are no longer made a part of the textbook. Two chapters are } \\
\text { added addressing Begum Salma Tassaduq and Molana Zafar Ali Khan as instrumental } \\
\text { leaders in the independence movement. } \\
\text { - While depicting } 1947 \text { partition, the textbook says that Indians treated Muslims leaving for } \\
\text { Pakistan very cruelly while Muslims in Pakistan were very kind to Hindus migrating to India } \\
\text { (Muasharti Aloom Chauthi Jamat kay liay, 2002, p. 85). } \\
\text { - The section on Indo-Pakistani War of } 1965 \text { explains "Pakistan as handing a clear defeat to } \\
\text { India" (Muasharti Aloom Chauthi Jamat kay liay, 2002, p. 86). }\end{array}$ \\
\hline 2012 & $\begin{array}{l}\text { - Contents on war heroes and wars are removed from the } 2012 \text { textbook. Only at one place, a } \\
\text { small image shows } 10 \text { soldiers and even the details concerning them are not given as to which } \\
\text { soldiers fought in which war (Ahmad et al., 2012, p. 43). } \\
\text { - The chapter on culture has sections such as "Getting Along with Others," "Definition of } \\
\text { Peace," "Definition of Conflict," "Possible Results of Peace and Possible Consequences of } \\
\text { Conflict," "Attitudes That Give Birth to Conflicts and Peace," "Ways to Establish Peace," } \\
\text { and "Ways of Resolving Conflict" Ahmad et al., 2012, pp. 111-115). } \\
\text { - The definition of peace in this textbook mentions tolerance and peace as the core values of } \\
\text { Islam. It says, "Islam, our religion, teaches us peace. All other religions give the message of } \\
\text { peace too" (Ahmad et al., p. 111). } \\
\text { - A stark shift in military revisionism and the norms of war are covered in the section } \\
\text { addressing ways of resolving conflict. The four methods listed are cooperation, dialogue, } \\
\text { compromise and arbitration (Ahmad et al., 2012, pp. 114-115). } \\
\text { - One of the chapters discussing important personalities mentions Sufi saint, Hazrat Baba Farid } \\
\text { Ganj Shakkar, Begam Jahan Ara Nawaz and Dr Allama Iqbal. These choices show "gender } \\
\text { and religious diversity in history textbook content". }\end{array}$ \\
\hline
\end{tabular}




\begin{tabular}{|l|l|}
\hline - The first time "a history textbook mentions civil war is in this textbook (Ahmad et al., 2012), \\
even though the Indo-Pakistani War of 1971, in which people in East Pakistan rebelled \\
against the government, is not discussed in civil war terms". \\
- Six aspects are given in detail in a portion "Possible Consequences of Conflict" (Ahmad et \\
al., 2012, p. 113): destabilization, mental stress, civil war, bloodshed, war and revolution. \\
- A bullet point on war acknowledges that Pakistan has fought all three wars over Kashmir. \\
However, the 1971 war was also due to some other factors such as ethnic and language issues \\
between East and West Pakistan.
\end{tabular}

Sources: Same as for appendix-1

Appendix 3: Change in Regime and Its Impact on Curriculum Social Studies for Grade 4

\begin{tabular}{|c|c|}
\hline Year & Social Studies for Grade 4 (Discourse of Others) \\
\hline 1965 & $\begin{array}{l}\text { - Non-Muslims are not discussed in any specific context in the textbook. The origins of the } \\
\text { people of Pakistan and India are traced linking them to Aryans who arrived around 4,000 } \\
\text { years ago to the sub-continent. In describing Aryans, the textbook (1965) states, "They were } \\
\text { fair and tall, and their descendants are Pakistani, Indians, Iranians, Afghans, English, French, } \\
\text { and German" (Muasharti Aloom Ka Practical Atlas: Grade 4. 1965, p. 6). } \\
\text { - A chapter in the textbook mentions that Mughal emperor Jalal ud Din Muhammad Akbar, } \\
\text { (1965) married Hindu women to "make allies of Hindus in his kingdom". Moreover, he } \\
\text { started a new religion called Deen-e-Ilahi to eliminate Hindu-Muslim division in the } \\
\text { subcontinent (Muasharti Aloom Ka Practical Atlas:r Grade 4, 1965, p. 19). } \\
\text { - The textbook mentions the Mughal emperor Aurangzeb as the Darvesh King, who forgave } \\
\text { all un-Islamic taxes and led a simple life (Muasharti Aloom Ka Practical Atlas: Grade 4, } \\
\text { 1965, p. 22). }\end{array}$ \\
\hline 1981 & $\begin{array}{l}\text { - The First Chapter positions Muslims and Hindus as enemies ever since the beginning of their } \\
\text { interaction in the subcontinent. } \\
\text { - A chapter called, "History of Punjab," states that when Muslims arrived in these areas, the } \\
\text { Hindus started fights against them and Muslims defeated Hindu Rajas in these battles. } \\
\text { Muslim rulers treated Hindus very kindly and gave them complete religious freedom. } \\
\text { However, the Hindus were hostile to Muslims and when the British attacked the sub- } \\
\text { continent, the Hindus helped the British to occupy the sub-continent. They supported the } \\
\text { British in imposing hardships on Muslims of the sub-continent (Yasmin et al., 1981, p. 6). } \\
\text { - While speaking about mass migration after the partition of the subcontinent, the textbook } \\
\text { states that Muslims allowed Hindus residing in Pakistan to migrate peacefully to India while } \\
\text { Hindus and Sikhs committed atrocities on Muslims leaving India on a large scale. Children, } \\
\text { women and men, young and old alike were killed mercilessly and their properties were also } \\
\text { looted by Hindus and Sikhs (Yasmin et al., 1981, p. 8). } \\
\text { At another point, the chapter almost repeats itself from another part of the textbook (1981), } \\
\text { saying: "Bharat [India] has always been inimical to Pakistan. It tries to bring harm to Pakistan } \\
\text { whenever it finds an opportunity to do so. In September 1965, Indian armed forces crossed } \\
\text { the border into Pakistan at Wagah without a formal declaration of war. But the Pakistan army } \\
\text { repulsed the attack. People of Punjab manifested unprecedented passion for their country. } \\
\text { Those living in the border areas did not give way to fight" (Yasmin et al., 1981, p. 9). } \\
\text { The contents of the history textbook clearly show the following national policy directives } \\
\text { (1981). Moreover, content shows that the Arab version of Islam is promoted through this } \\
\text { book. For instance, the section on the Prophet Muhammad, mentions the modern state of } \\
\text { Saudi Arabia and gives detail of the ancient link of Prophet Muhammad to Mecca city. The } \\
\text { chapter explains that in the world there are many Muslim states. Saudi Arabia is famous for } \\
\text { all states. Muslims from all over the world go to perform Hajj to Saudi Arabia every year. } \\
\text { Prophet Muhammad (may God bless him and peace be upon him) was born in this Holy city } \\
\text { in the year } 571 \text { A.D (Yasmin et al., 1981, p. 65). }\end{array}$ \\
\hline 2002 & $\begin{array}{l}\text { - It retains the earlier narrative of textbooks of the } 1980 \text { s and showed that Ranjeet Singh's rule } \\
\text { in Punjab was notable in terms of cruelty and discrimination with the Muslims (Muasharti } \\
\text { Aloom Chauthi Jamat kay liay, 2002, p. 82). This textbook tells that India was quite cruel }\end{array}$ \\
\hline
\end{tabular}




\begin{tabular}{|c|c|}
\hline & $\begin{array}{l}\text { towards the Muslims leaving for Pakistan after partition in } 1947 \text { while Muslims in Pakistan } \\
\text { were quite kind to refugees leaving for India. (Muasharti Aloom Chauthi Jamat kay liay, } \\
2002 \text {, p. 85). }\end{array}$ \\
\hline 2012 & $\begin{array}{l}\text { - The } 2012 \text { textbook gives outcomes of students learning in the beginning. These details are } \\
\text { extracted from the National Curriculum of } 2006 \text {. They include a student's ability to } \\
\text { "recognize the viewpoints of the historians" (Ahmad et al., 2012, p. 20) and comprehend } \\
\text { diversity in perspectives on history. } \\
\text { - One of the chapters "Concept of a Hero," the textbook says, "A person may be [a] hero for } \\
\text { his nation or the followers of his religion but it is not necessary that the persons belonging to } \\
\text { some other nation or religion also consider him as their hero" (Ahmad et al., 2012, p. 44). } \\
\text { - The book at various places speaks about people other than Muslims and Pakistanis in } \\
\text { favourable terms. Earlier textbook presented non-Muslims as hostile. } \\
\text { - Buddha is portrayed in a section as a popular figure among people, disturbed by injustice in } \\
\text { society and searching for truth (Ahmad et al., 2012, p. 24). } \\
\text { - Textbooks in past years claimed that Hindus ruined Buddhism with idolatry. However, this } \\
\text { textbook does not bring up Hindus in talking about Buddhism. } \\
\text { - The textbook talks favourably of the British. In a section titled "British Regime 1894-1947 } \\
\text { A.D.," the content depicting history leads to complexity than "a one-sided good-versus-evil } \\
\text { account of history". The textbook provides information that the British got hold of the region } \\
\text { by defeating the local people. } \\
\text { - Many reforms were introduced by the British for the welfare of people in Punjab. They } \\
\text { reformed the education department, police department, transportation system etc. However, } \\
\text { many movements against British rule started in this period. } \\
\text { - The Pakistan Resolution passed on } 23^{\text {rd }} \text { March } 1940 \text { at Lahore (Punjab) (Ahmad et al., 2012, } \\
\text { p. } 30 \text { ). }\end{array}$ \\
\hline
\end{tabular}

Sources: Same as for appendix 1 